\title{
Non Regular Use of a Neutraceutical in Control of Type 2 Diabetes with Dislipidaemia
}

\author{
Analava Mitra* and D. Bhattacharya** \\ * B.C. Roy Tech Hospital \& Adjunct Faculty, School of Medical Science and Technology, \\ Indian Institute of Technology, Kharagpur 721 302, West Bengal, India \\ Telephone: 03222-282657; Fax: 03222-282631; E-mail: amitra@adm.iitkgp.ernet.in \\ ** Chemical Engineering Department, Indian Institute of Technology, Kharagpur 721 302, \\ West Bengal, India
}

KEYWORDS Type 2 Diabetes. Flax Oil. Fenugreek. Sesame Oil

\begin{abstract}
Type 2 diabetes is growing explosively in India. The exact cause being unknown and both nature and nurture are believed to have role. Diet and lifestyle of Indians are blamed for the increase. Majority of Indians are lacto-vegetarians and do not culturally permit all kind of food. Further, Indians being poor the dietary ingrediant, must be affordable. Health infrastructure in rural India is poor and hence neutraceutical aided control is helpful in villagers. A particular food composite used daily reduces the compliance and hence alternative approaches like use of different sets of neutraceuticals or use of same neutraceuticals not on daily basis is suggested. Chances are there that on non daily use the beneficial effects of neutraceutical may reduce. This study shows that flax oil and fenugreek with sesame oil used as the cooking medium, a neutraceutical of use in diabetes remains effective on non regular use rather the effect potentiates on being used at two days interval.
\end{abstract}

\section{INTRODUCTION}

As per King et al. (1998) incidence of diabetes in India will increase by 195\% in 2025 and the sufferers will be young age individuals. Type 2 diabetes as a result of Insulin Resistance (IR) is commonly associated with Obesity, hypertension, Coronary Artery Disease (CAD) and Dyslipidaemia (Grant, 2006; Reaven, 1988). Diet has a profound role in the control of such diseases (Mitra and Bhattacharya, 2005 and 2006; Ghafoarunissa, 1996; Raheja et al., 1970; Luscombe et al., 2002; Ornish, 1996). This is of particular importance in India as different dimensions of health related services are grossly inadequate (Park, 2000). The median annual direct medical cost for patient with Type-2 DM without complications was Rs. 14,507/ -. The cost of treatment of this disease per se and its accompanying complications can ruin families (Bhaskaran et al., 2003). Hence different combinations of food substances having antidiabetic effects is an ideal solution in Indian rural scenario. Studies by Mitra (2002) and Mitra and Bhattacharjee (2006) had revealed that flax oil and fenugreek with sesame oil used as the cooking medium reduces blood sugar and bad cholesterols in a diabetic both in short term studies (12 months) and in long term studies ( 9 years).

To maintain dietary compliance is very tough. This study is conducted with flax oil and fenugreek with sesame oil used as the cooking medium where these items are used daily, on alternate days, on two days interval and on three days interval and the effects are observed and compared. Identical results in different settings will naturally induce more compliance.

\section{METHODOLOGY}

Amongst the 100 persons under study (1 year period), 5 homogeneous groups of 20 patients were selectively chosen (Alderson and Robin, 1979; Abramson, 1979). 20 patients formed a control group, which received normal rural diet. Written consents of the patients for compliance were obtained before the study. The patients were symptomatically normal and had no signs and symptoms of any disease except the altered biochemical parameters of type 2 diabetes. The patients were without any anti-hypertensive, lipid lowering or drug therapies and underwent clinical and anthropometrical evaluations before and after the study. Initial biochemical evaluations were also conducted before the study.

Blood samples from the patients were taken by an indwelling catheter in the ante-cubital vein and effects on fasting blood sugar (FBS) and lipid profiles, total cholesterol (TC), low density lipoprotein cholesterol (LDL), very low density lipoprotein cholesterol (VLDL), high density 
lipoprotein cholesterol (HDL), and triglycerides (TG) were tested in respect of separate groups receiving separate directions of intake and comparing each of the above parameters with the group receiving usual rural diet. The tests were conduc-ted as per Instruction sheets for manual assays given by Boehringer Mannheim Limited (1983) and the instrument used was photometer 4010 (Boehringer, Germany). Serum insulin values of all the volunteers were measured at the beginning and at the end of the experiment by radio-immunoassay.

During the period of study identical conditions were maintained so that the effects could be compared. Regular diet of the subjects of contained mostly of cereals and pulses. Different food substances were to be used in the study mixed together in different proportions observing maximum palatability. Raw ingredients were purchased from local market. The patients were given dietary advises as per American Diabetic Association guidelines and were also advised walk fit programme (ADA, 1987; Snowdon and Humphreys, 1993).

Patients were on usual rural diet, which constituted $70-80 \%$ of carbohydrates, $10-20 \%$ of proteins and about $10 \%$ of fats (Mitra and Bhattacharya, 2006). The blood biochemistry values of desired parameters were obtained quarterly and analyzed taking the data for a complete year. The amount of each neutraceutical was arrived at, with considerations of acceptability and affordability of the patients. Flax oil, mixed with requisite quantity of chilli powder $(5 \mathrm{~g} / 15 \mathrm{ml})$, was given at 1 tablespoonful/day as a salad oil. Chilli being rich in anti-oxidant gives the protection of flax oil besides masking its insipid taste (Monsereenusorn et al., 1982; Govindarajan and Sathyanarayana, 1991). Fenugreek seed powder was incorporated in Chapatis each containing about $5 \mathrm{~g}$ of fenugreek. Total fenugreek consumption was $25 \mathrm{~g}$ a day (American Botanical Council, 1998; Newall et al., 1996). While mustard oil, sesame oil, sunflower oil etc. could be used as cooking medium, the more easily degradable flax oil could be used only as salad oil and its daily consumption of about 15 - $20 \mathrm{~g}$ was sufficient (Cunnane and Thompson, 1995). Average cooking oil consumption was maintained at $30 \mathrm{ml} /$ day during the periods of study (Roy, 2000). Sesame oil was procured from the local market while flax oil was extracted locally from good quality seeds by village level ghani.

\section{RESULTS}

The volunteers for the study (100 NIDDM patients) underwent clinical, anthropometrical evaluation before the study. The observations were:

The observations were:

Age $-49.16 \pm 4.25$ years

Sex: males - 50, females-50

Weight: $69.75 \pm 6.40 \mathrm{~kg}$,

Body Mass Index (BMI): $22.10 \pm 1.13$.

At the end of the study it was found that in the volunteers the weight became $69.78 \pm 6.23 \mathrm{~kg}$ and BMI was found to be $22.32 \pm 3.12$, this variation may be non-identical conditions prevailing during measurements. Initial blood samples as analysed for plasma glucose and lipid profile were shown in the table below. As the samples were drawn from different patients, having different socio-cultural backgrounds, considering the diversity of Indian population in intake of food, life-styles, socio-cultural believes etc, the variations in the initial readings of different blood parameters in different patients were noted. Clinical Parameters were evaluated at the end of study. All the parameters remained as like before except Blood Pressure values which showed decrease of Systolic Blood Pressure of $10 \mathrm{~mm}$ of $\mathrm{Hg}(\mathrm{p}=0.5)$ which may be due to changes in rheological properties of blood (Cunnane \& Thompson, 1995). SGPT values in the experimental group were increased by 8 units in the 4 th week and it remained stationary after that $(p \leq 0.25)$. The effects may be due to inhibition of enzymatic reactions by the oil and needs further study.

Effects of daily intake of flax oil and fenugreek with sesame oil as cooking media were plotted in table 1. It was found that TLC was reduced from $260 \pm 11 \mathrm{mg} / \mathrm{dl}$ to $240 \pm 09 \mathrm{mg} / \mathrm{dl}$ at the end of study $(\mathrm{p} \leq 0.050)$. HDLC was increased from $58 \pm 05 \mathrm{mg} / \mathrm{dl}$ to $68 \pm 05 \mathrm{mg} / \mathrm{dl}(\mathrm{p} \leq 0.050)$. LDLC was reduced from $178 \pm 10 \mathrm{mg} / \mathrm{dl}$ to $170 \pm 09 \mathrm{mg} / \mathrm{dl}(\mathrm{p} \leq 0.25)$. VLDLC was reduced from $45 \pm 08 \mathrm{mg} / \mathrm{dl}$ to $42 \pm 07 \mathrm{mg} / \mathrm{dl}$ $(\mathrm{p} \leq 0.050)$. TG was reduced from $225 \pm 11 \mathrm{mg} / \mathrm{dl}$ to $210 \pm 08 \mathrm{mg} / \mathrm{dl}(\mathrm{p} \leq 0.025)$. FBS was reduced from $172 \pm 16 \mathrm{mg} / \mathrm{dl}$ to $160 \pm 05 \mathrm{mg} / \mathrm{dl}(\mathrm{p} \leq 0.050)$.

The results of giving combination of sesame oil, flax oil and fenugreek on alternate days were plotted in Table 2 (Effects of sesame oil, flax oil and fenugreek consumed on alternate days). TLC was reduced from $300 \pm 08 \mathrm{mg} / \mathrm{dl}$ initially to $284 \pm 09$ $\mathrm{mg} / \mathrm{dl}$ at the end $(\mathrm{p}=0.050)$. HDLC was increased 
Table 1: Effects of Sesame Oil, Flax Oil And Fenugreek Consumed Daily

\begin{tabular}{|c|c|c|c|c|c|c|}
\hline $\begin{array}{l}\text { Time } \\
\text { (in months) }\end{array}$ & $\begin{array}{l}T L C \\
(m g / d l)\end{array}$ & $\begin{array}{l}H D L C \\
(m g / d l)\end{array}$ & $\begin{array}{l}L D L C \\
(m g / d l)\end{array}$ & $\begin{array}{l}V L D L C \\
(m g / d l)\end{array}$ & $\begin{array}{l}T G \\
(m g / d l)\end{array}$ & $\begin{array}{l}F B S \\
(m g / d l)\end{array}$ \\
\hline 1 & $260 \pm 11$ & $58 \pm 5$ & $178 \pm 10$ & $45 \pm 8$ & $225 \pm 11$ & $172 \pm 16$ \\
\hline 2 & $250 \pm 6$ & $60 \pm 6$ & $170 \pm 14$ & $44 \pm 6$ & $220 \pm 19$ & $175 \pm 09$ \\
\hline 3 & $255 \pm 9$ & $60 \pm 5$ & $170 \pm 11$ & $44 \pm 5$ & $220 \pm 8$ & $175 \pm 11$ \\
\hline 4 & $250 \pm 8$ & $62 \pm 7$ & $175 \pm 10$ & $44 \pm 4$ & $220 \pm 4$ & $175 \pm 07$ \\
\hline 5 & $250 \pm 6$ & $64 \pm 3$ & $180 \pm 12$ & $40 \pm 6$ & $202 \pm 11$ & $175 \pm 15$ \\
\hline 6 & $245 \pm 7$ & $64 \pm 4$ & $180 \pm 08$ & $41 \pm 5$ & $206 \pm 13$ & $170 \pm 11$ \\
\hline 7 & $250 \pm 7$ & $64 \pm 7$ & $180 \pm 10$ & $44 \pm 7$ & $220 \pm 9$ & $170 \pm 15$ \\
\hline 8 & $245 \pm 6$ & $66 \pm 5$ & $175 \pm 16$ & $46 \pm 5$ & $230 \pm 11$ & $165 \pm 8$ \\
\hline 9 & $245 \pm 13$ & $58 \pm 4$ & $182 \pm 11$ & $39 \pm 6$ & $194 \pm 7$ & $163 \pm 5$ \\
\hline 10 & $242 \pm 5$ & $68 \pm 3$ & $184 \pm 10$ & $39 \pm 4$ & $194 \pm 9$ & $160 \pm 5$ \\
\hline 11 & $240 \pm 9$ & $68 \pm 3$ & $175 \pm 7$ & $40 \pm 5$ & $200 \pm 12$ & $160 \pm 7$ \\
\hline 12 & $240 \pm 9$ & $68 \pm 5$ & $170 \pm 9$ & $42 \pm 7$ & $210 \pm 8$ & $160 \pm 5$ \\
\hline
\end{tabular}

Table 2: Effects of sesame oil, flax oil and fenugreek consumed on alternate days

\begin{tabular}{lllllll}
\hline $\begin{array}{l}\text { Time } \\
(\text { in months })\end{array}$ & $\begin{array}{l}T L C \\
(m g / d l)\end{array}$ & $\begin{array}{l}H D L C \\
(m g / d l)\end{array}$ & $\begin{array}{l}L D L C \\
(m g / d l)\end{array}$ & $\begin{array}{l}V L D L C \\
(m g / d l)\end{array}$ & $\begin{array}{l}T G \\
(m g / d l)\end{array}$ & $\begin{array}{l}F B S \\
(m g / d l)\end{array}$ \\
\hline 1 & $300 \pm 8$ & $45 \pm 3$ & $210 \pm 10$ & $44 \pm 2$ & $220 \pm 7$ & $152 \pm 10$ \\
2 & $292 \pm 6$ & $50 \pm 4$ & $195 \pm 8$ & $43 \pm 3$ & $213 \pm 9$ & $146 \pm 11$ \\
3 & $292 \pm 4$ & $51 \pm 2$ & $195 \pm 10$ & $42 \pm 2$ & $210 \pm 8$ & $144 \pm 9$ \\
4 & $295 \pm 9$ & $52 \pm 3$ & $195 \pm 10$ & $42 \pm 4$ & $210 \pm 4$ & $146 \pm 7$ \\
5 & $292 \pm 6$ & $53 \pm 3$ & $200 \pm 10$ & $43 \pm 2$ & $215 \pm 6$ & $146 \pm 8$ \\
6 & $290 \pm 4$ & $54 \pm 4$ & $195 \pm 10$ & $43 \pm 3$ & $215 \pm 6$ & $146 \pm 11$ \\
7 & $288 \pm 7$ & $55 \pm 2$ & $195 \pm 10$ & $42 \pm 2$ & $210 \pm 9$ & $146 \pm 9$ \\
8 & $289 \pm 6$ & $56 \pm 3$ & $198 \pm 10$ & $41 \pm 3$ & $205 \pm 7$ & $144 \pm 8$ \\
9 & $290 \pm 7$ & $57 \pm 4$ & $200 \pm 10$ & $41 \pm 2$ & $205 \pm 11$ & $144 \pm 7$ \\
10 & $287 \pm 5$ & $57 \pm 3$ & $200 \pm 10$ & $40 \pm 4$ & $202 \pm 4$ & $140 \pm 5$ \\
11 & $287 \pm 9$ & $57 \pm 3$ & $200 \pm 10$ & $40 \pm 2$ & $202 \pm 8$ & $144 \pm 9$ \\
12 & $284 \pm 9$ & $57 \pm 5$ & $200 \pm 10$ & $40 \pm 4$ & $202 \pm 6$ & $140 \pm 9$ \\
\hline
\end{tabular}

from $45 \pm 03 \mathrm{mg} / \mathrm{dl}$ to $57 \pm 05 \mathrm{mg} / \mathrm{dl}(\mathrm{p} \leq 0.050)$. LDLC was reduced from $210 \pm 10 \mathrm{mg} / \mathrm{dl}$ to $200 \pm 10 \mathrm{mg} / \mathrm{dl}$ $(\mathrm{p} \leq 0.25)$. VLDLC was reduced from $44 \pm 02 \mathrm{mg} / \mathrm{dl}$ to $40 \pm 04 \mathrm{mg} / \mathrm{dl}(\mathrm{p} \leq 0.050)$. TG was reduced from $220 \pm 07 \mathrm{mg} / \mathrm{dl}$ to $202 \pm 06 \mathrm{mg} / \mathrm{dl}(\mathrm{p} \leq 0.025)$. FBS was reduced from $152 \pm 10 \mathrm{mg} / \mathrm{dl}$ to $140 \pm 09 \mathrm{mg} / \mathrm{dl}$ $(\mathrm{p} \leq 0.050)$.

Results of giving combination of sesame oil, flax oil and fenugreek on two days interval (Table 3) showed TLC was reduced from $310 \pm 7 \mathrm{mg} / \mathrm{dl}$ to $284 \pm 9 \mathrm{mg} / \mathrm{dl}(\mathrm{p} \leq 0.050)$. HDLC was increased from $45 \pm 5 \mathrm{mg} / \mathrm{dl}$ to $57 \pm 5 \mathrm{mg} / \mathrm{dl}(\mathrm{p} \leq 0.050)$. LDLC was reduced from $230 \pm 8 \mathrm{mg} / \mathrm{dl}$ to $200 \pm 10 \mathrm{mg} / \mathrm{dl}$ $(\mathrm{p} \leq 0.025)$. VLDLC was reduced from $35 \pm 6 \mathrm{mg} / \mathrm{dl}$ to $27 \pm 04 \mathrm{mg} / \mathrm{dl}(\mathrm{p} \leq 0.025)$. TG was reduced from $175 \pm 9 \mathrm{mg} / \mathrm{dl}$ to $135 \pm 6 \mathrm{mg} / \mathrm{dl}(\mathrm{p} \leq 0.025)$. FBS was reduced from $152 \pm 12 \mathrm{mg} / \mathrm{dl}$ to $140 \pm 9 \mathrm{mg} / \mathrm{dl}$ $(\mathrm{p} \leq 0.050)$. A two-sample t-test was performed for pair-wise comparison of the groups and it was found that there was no significant difference, particularly on FBS values as a result of daily or alternate day consumption of the combination but the results showed more improvement, particularly in control of VLDLC and TG when the combination was taken at two days interval.

Results of giving combination of sesame oil, flax oil and fenugreek on three days interval (Table 4) showed TLC was reduced from $310 \pm 6 \mathrm{mg} / \mathrm{dl}$ to $302 \pm 9 \mathrm{mg} / \mathrm{dl}(\mathrm{p} \leq 0.25)$. HDLC was increased from $45 \pm 6 \mathrm{mg} / \mathrm{dl}$ to $49 \pm 5 \mathrm{mg} / \mathrm{dl}(\mathrm{p} \leq 0.50)$. LDLC was reduced from $235 \pm 6 \mathrm{mg} / \mathrm{dl}$ to $228 \pm 7 \mathrm{mg} / \mathrm{dl}$ $(\mathrm{p} \leq 0.075)$. VLDLC was reduced from $28 \pm 5 \mathrm{mg} / \mathrm{dl}$ to $25 \pm 04 \mathrm{mg} / \mathrm{dl}(\mathrm{p} \leq 0.050)$. TG was reduced from $140 \pm 8 \mathrm{mg} / \mathrm{dl}$ to $125 \pm 8 \mathrm{mg} / \mathrm{dl}(\mathrm{p} \leq 0.050)$. FBS was reduced from $158 \pm 8 \mathrm{mg} / \mathrm{dl}$ to $151 \pm 6 \mathrm{mg} / \mathrm{dl}$ $(p \leq 0.075)$. Taking the food composite in three days interval showed less affectivity in all parameters. Hence the optimum result was derived on consumption at two days interval. This was also supported by serum insulin value analysis, which showed insulin sensitivity increases maximally with sesame oil, flax oil and fenugreek taken at two days interval Table 5 was showing the effects of rural Bengalee diet in control population and used for comparison.

Analyzing the values it was observed that TLC, HDLC, LDLC, VLDLC, TG and FBS values did not change with rural Bengalee diet. However, 
the serum insulin value was increased with rural Bengalee diet showing rural diet was diabetogenic in nature (Mitra and Bhattacharya, 2006).

Measuring for insulin sensitivity or insulin resistance by HOMA 2 showed insulin sensitivity was increased and taking the composite at two days interval reduced insulin resistance (Table 6 showing the serum insulin values in different groups in 12 hour fasting samples). Exact reason was unknown and needed further study.

Table 3: Effects of Sesame Oil, Flax Oil and Fenugreek consumed on two days interval

\begin{tabular}{|c|c|c|c|c|c|c|}
\hline $\begin{array}{l}\text { Time } \\
\text { (in months) }\end{array}$ & $\begin{array}{l}T L C \\
(m g / d l)\end{array}$ & $\begin{array}{l}H D L C \\
(m g / d l)\end{array}$ & $\begin{array}{l}L D L C \\
(m g / d l)\end{array}$ & $\begin{array}{l}V L D L C \\
(m g / d l)\end{array}$ & $\begin{array}{l}T G \\
(m g / d l)\end{array}$ & $\begin{array}{l}F B S \\
(m g / d l)\end{array}$ \\
\hline 1 & $310 \pm 7$ & $45 \pm 5$ & $230 \pm 8$ & $35 \pm 6$ & $175 \pm 9$ & $152 \pm 12$ \\
\hline 2 & $306 \pm 9$ & $46 \pm 3$ & $228 \pm 11$ & $34 \pm 5$ & $172 \pm 8$ & $152 \pm 11$ \\
\hline 3 & $304 \pm 8$ & $46 \pm 5$ & $225 \pm 13$ & $33 \pm 5$ & $167 \pm 6$ & $154 \pm 13$ \\
\hline 4 & $305 \pm 5$ & $47 \pm 6$ & $225 \pm 9$ & $33 \pm 7$ & $165 \pm 12$ & $153 \pm 9$ \\
\hline 5 & $304 \pm 11$ & $46 \pm 4$ & $223 \pm 11$ & $34 \pm 7$ & $168 \pm 7$ & $151 \pm 12$ \\
\hline 6 & $304 \pm 9$ & $48 \pm 7$ & $224 \pm 6$ & $32 \pm 6$ & $162 \pm 9$ & $149 \pm 7$ \\
\hline 7 & $302 \pm 8$ & $48 \pm 6$ & $222 \pm 8$ & $32 \pm 8$ & $160 \pm 6$ & $148 \pm 8$ \\
\hline 8 & $299 \pm 7$ & $49 \pm 5$ & $223 \pm 9$ & $28 \pm 5$ & $145 \pm 7$ & $147 \pm 11$ \\
\hline 9 & $298 \pm 8$ & $52 \pm 5$ & $222 \pm 12$ & $26 \pm 6$ & $135 \pm 9$ & $144 \pm 9$ \\
\hline 10 & $297 \pm 6$ & $52 \pm 4$ & $221 \pm 8$ & $26 \pm 5$ & $132 \pm 8$ & $143 \pm 8$ \\
\hline 11 & $297 \pm 9$ & $53 \pm 5$ & $220 \pm 9$ & $26 \pm 5$ & $132 \pm 11$ & $144 \pm 9$ \\
\hline 12 & $284 \pm 9$ & $57 \pm 5$ & $200 \pm 10$ & $27 \pm 04$ & $135 \pm 6$ & $140 \pm 9$ \\
\hline
\end{tabular}

Table 4: Effects of sesame oil, flax oil and fenugreek consumed on three days interval

\begin{tabular}{|c|c|c|c|c|c|c|}
\hline $\begin{array}{l}\text { Time } \\
\text { (in months) }\end{array}$ & $\begin{array}{l}T L C \\
(m g / d l)\end{array}$ & $\begin{array}{l}H D L C \\
(m g / d l)\end{array}$ & $\begin{array}{l}L D L C \\
(m g / d l)\end{array}$ & $\begin{array}{l}V L D L C \\
(m g / d l)\end{array}$ & $\begin{array}{l}T G \\
(m g / d l)\end{array}$ & $\begin{array}{l}F B S \\
(m g / d l)\end{array}$ \\
\hline 1 & $310 \pm 6$ & $45 \pm 6$ & $235 \pm 6$ & $28 \pm 5$ & $140 \pm 8$ & $158 \pm 8$ \\
\hline 2 & $310 \pm 8$ & $45 \pm 5$ & $234 \pm 11$ & $29 \pm 7$ & $144 \pm 7$ & $158 \pm 7$ \\
\hline 3 & $309 \pm 7$ & $45 \pm 3$ & $235 \pm 7$ & $29 \pm 5$ & $144 \pm 6$ & $157 \pm 9$ \\
\hline 4 & $309 \pm 5$ & $46 \pm 6$ & $235 \pm 9$ & $28 \pm 7$ & $142 \pm 8$ & $158 \pm 7$ \\
\hline 5 & $307 \pm 7$ & $46 \pm 4$ & $233 \pm 8$ & $28 \pm 5$ & $140 \pm 6$ & $156 \pm 6$ \\
\hline 6 & $308 \pm 8$ & $47 \pm 4$ & $234 \pm 6$ & $27 \pm 5$ & $137 \pm 7$ & $153 \pm 8$ \\
\hline 7 & $306 \pm 6$ & $48 \pm 5$ & $232 \pm 5$ & $26 \pm 7$ & $130 \pm 5$ & $155 \pm 7$ \\
\hline 8 & $306 \pm 8$ & $47 \pm 3$ & $233 \pm 7$ & $26 \pm 6$ & $130 \pm 7$ & $152 \pm 6$ \\
\hline 9 & $305 \pm 7$ & $47 \pm 4$ & $232 \pm 6$ & $26 \pm 6$ & $130 \pm 8$ & $154 \pm 8$ \\
\hline 10 & $305 \pm 9$ & $48 \pm 4$ & $231 \pm 5$ & $26 \pm 5$ & $132 \pm 8$ & $153 \pm 7$ \\
\hline 11 & $303 \pm 11$ & $49 \pm 6$ & $230 \pm 9$ & $24 \pm 5$ & $126 \pm 9$ & $151 \pm 8$ \\
\hline 12 & $302 \pm 9$ & $49 \pm 5$ & $228 \pm 7$ & $25 \pm 04$ & $125 \pm 8$ & $151 \pm 6$ \\
\hline
\end{tabular}

Table 5: Effects of rural Bengalee diet in control population

\begin{tabular}{lllllll}
\hline $\begin{array}{l}\text { Time } \\
\text { (in months })\end{array}$ & $\begin{array}{l}\text { TLC } \\
(\mathrm{mg} / \mathrm{dl})\end{array}$ & $\begin{array}{l}\mathrm{HDLC} \\
(\mathrm{mg} / \mathrm{dl})\end{array}$ & $\begin{array}{l}\text { LDLC } \\
(\mathrm{mg} / \mathrm{dl})\end{array}$ & $\begin{array}{l}\text { VLDLC } \\
(\mathrm{mg} / \mathrm{dl})\end{array}$ & $\begin{array}{l}\text { TG } \\
(\mathrm{mg} / \mathrm{dl})\end{array}$ & $\begin{array}{l}F B S \\
(\mathrm{mg} / \mathrm{dl})\end{array}$ \\
\hline 1 & $210 \pm 10$ & $56 \pm 05$ & $136 \pm 09$ & $18 \pm 03$ & $94 \pm 07$ & $124 \pm 06$ \\
2 & $212 \pm 11$ & $56 \pm 04$ & $138 \pm 11$ & $18 \pm 02$ & $94 \pm 04$ & $122 \pm 08$ \\
3 & $212 \pm 09$ & $56 \pm 03$ & $138 \pm 07$ & $18 \pm 03$ & $94 \pm 09$ & $122 \pm 06$ \\
4 & $215 \pm 07$ & $58 \pm 05$ & $139 \pm 06$ & $18 \pm 05$ & $94 \pm 11$ & $122 \pm 12$ \\
5 & $214 \pm 08$ & $57 \pm 02$ & $138 \pm 10$ & $18 \pm 02$ & $94 \pm 07$ & $124 \pm 09$ \\
6 & $214 \pm 11$ & $57 \pm 02$ & $136 \pm 09$ & $19 \pm 04$ & $98 \pm 05$ & $126 \pm 16$ \\
7 & $212 \pm 09$ & $56 \pm 04$ & $136 \pm 11$ & $20 \pm 03$ & $102 \pm 11$ & $125 \pm 12$ \\
8 & $212 \pm 08$ & $56 \pm 03$ & $136 \pm 07$ & $20 \pm 05$ & $102 \pm 05$ & $125 \pm 04$ \\
9 & $212 \pm 07$ & $56 \pm 04$ & $136 \pm 04$ & $20 \pm 02$ & $102 \pm 09$ & $126 \pm 07$ \\
10 & $210 \pm 05$ & $56 \pm 04$ & $136 \pm 04$ & $18 \pm 02$ & $94 \pm 03$ & $124 \pm 03$ \\
\hline
\end{tabular}

Table 6: Serum insulin values in different groups (12 hour fasting)

\begin{tabular}{llllll}
\hline $\begin{array}{l}\text { Serum insulin } \\
\text { values }\end{array}$ & $\begin{array}{l}\text { Rural diet } \\
\text { only }\end{array}$ & $\begin{array}{l}\text { Composite } \\
\text { daily }\end{array}$ & $\begin{array}{l}\text { Composite on } \\
\text { alternate day }\end{array}$ & $\begin{array}{l}\text { Composite on two } \\
\text { days interval }\end{array}$ & $\begin{array}{l}\text { Composite on three } \\
\text { days interval }\end{array}$ \\
\hline Initial & $42 \pm 4 \mu \mathrm{iu} / \mathrm{ml}$ & $40 \pm 5 \mu \mathrm{iu} / \mathrm{ml}$ & $42 \pm 7 \mu \mathrm{iu} / \mathrm{ml}$ & $43 \pm 6 \mu \mathrm{iu} / \mathrm{ml}$ & $39 \pm 6 \mu \mathrm{iu} / \mathrm{ml}$ \\
End & $44 \pm 5 \mu \mathrm{iu} / \mathrm{ml}$ & $38 \pm 4 \mu \mathrm{iu} / \mathrm{ml}$ & $39 \pm 6 \mu \mathrm{iu} / \mathrm{ml}$ & $36 \pm 5 \mu \mathrm{iu} / \mathrm{ml}$ & $37 \pm 7 \mu \mathrm{iu} / \mathrm{ml}$ \\
\hline
\end{tabular}




\section{CONCLUSION}

In a developing country like India neutraceutical oriented control of diabetes is the need of the hour. The composite already tested to have good effect in a diabetic is sesame oil, flax oil and fenugreek. Taking the same composite daily will reduce the compliance and ultimately will be less effective. It was found that daily consumption of the composite is less effective than taking on two days interval. This increases the patient compliance and gives scope to more verities of neutraceuticals to be used and tested. The exact cause of such phenomenon being unknown may be due to more recruits of insulin receptors or more priming of receptor cells to insulin effects.

\section{REFERENCES}

Abramson, J.H.: Survey methods in community Medicine, 2nd Edition. Churchill Livingstone, Harcourt, Mosby (1979).

ADA.: Nutritional recommendations and principles for people with diabetes mellitus. Diabetes Care, 23(1): 1-9 (1987).

Alderson, M.R. and Robin, D.: Health Surveys and Related Studies. Pergamon Press, New York (1979). American Botanical Council (Corporate Author), Mark, Blumenthal, Werner, R. Busse, Alicia, Goldberg, Joerg, Gruenwald, Tara, Hall, Chance, W. Riggins, Robert, S. Rister, Sigrid, A. Klein: The Complete German Commission E Monograph: Therapeutic Guide to Herbal Medicines. American Botanical Council, Austin TX (1998)

Bhaskaran, V.P., Rau, N.R., Satyashankar, Acharya, Ravi Raj, Chinnappa, S. Metgud, Koshy, A. Tarun: Study of the direct costs incurred by type- 2 diabetes mellitus patients for their treatment at a large tertiary-care hospital in Karnataka. India Journal of the Academy of Hospital Administration, 15(2): 7-12 (2003).

Boehringer Mannheim: Instruction sheets for manual assays. GmbH diagnostics: Catalogue no.124095 (cholesterol), diagnostics Catalogue no 543004 (HDLC), diagnostics Catalogue no 124966 (Triglycerides), Catalogue no.263 826 (Glucose), Catalogue no.400 971 and catalogue no. 543004 (LDLC and VLDLC). Germany 6800 Mannheim 31, Boehringer Mannheim GmbH (1983).

Cunnane, S.C. and Thompson, L.U.: Flaxseed in human nutrition. American Oil Chemist Society Press, Champaign, Illinois (1995).

Ghafoarunissa: Fats in Indian diets and their nutritional and health implications. Lipids, 31(Supplement): 287-291 (1996)

Govindarajan, V.S. and Sathyanarayana, M.N.: Capsicumproduction, technology, chemistry and quality. Part V. Impact on physiology, pharmacology, nutrition, and metabolism, structure, pungency, pain and desensitization, sequences. Food Science Nutrition, 29: 435-74 (1991).

Grant, J. Peter: The Neel hypothesis revisited. Lecture in seminar on Diabetes and Cardiovascular Disease in Sydney, May 7th, 2006 (2006).

King, H., Aubert, R.E. and Herman, W.H.: Global burden of diabetes, 1995-2025: Prevalence, numerical estimates, and projections. Diabetes Care, 21: 141431 (1998).

Luscombe, N.D., Clifton, P.M., Noakes, M., Parker, B. and Wittert, G.: Effects of energy-restricted diets containing increased protein on weight loss, resting energy expenditure, and the thermic effect of feeding in type 2 diabetes. Diabetes Care, 25: 652-657 (2002).

Mitra, A. and Bhattacharya, D.: Effects of overall consumption, dietary patterns, cooking, on patients suffering from non insulin dependent diabetes mellitus. Journal of Interacademicia, 9(4): 635-642 (2005).

Mitra, A. and Bhattacharya, D.: Effect of fatty substances on health particularly to patients suffering from NIDDM and dyslipidaemia. Journal of Interacademicia, 10(1): $74-85$ (2006).

Mitra, Analava: Neutraceuticals for Control of Non-Insulin Dependent Diabetes Mellitus. Ph.D. Thesis (unpublished). IIT, Kharagpur (2002).

Mitra, Analava and Bhattacharya, Debaprasad: Effects of long term study of combination of neutraceuticals in non-insulin- dependent diabetes mellitus patients. Journal of Food Science \& Technology, 43(5): 477 483 (2006).

Monsereenusorn, Y., Kongsamut, S. and Pezalla, P.D.: Capsaicin: a literature survey. CRC Critical Reviews in Toxicology, 10: 321-39 (1982).

Newall, C.A., Anderson, L.A. and Phillipson, J.D.: Herbal Medicines: A Guide for Health-Care Professionals. The Pharmaceutical Press, London (1996).

Ornish, Dean: Program for Reversing Heart Disease. Ivy Books, New York (1996).

Park, K.: Park's Textbook of Preventive and Social Medicine. Banarsi Das Bhanot, Jabalpur (2000).

Raheja, B.S., Talwalkar, N.G. and Suttarwalla, S.K.: Ischaemic heart disease in diabetes. Journal of Association of Physicians of India, 18(2): 261-67 (1970).

Reaven, G.M.: Banting Lecture 1988. Role of insulin resistance in human disease Diabetes, 37(12): 15951607 (1988).

Roy, S. K. Quest for fats and oils in the new millennium. Paper in Regional workshop on oilseeds and oils, Calcutta June 21 to 22, 2000 (2000).

Snowdon, L. and Humphreys, M.: Fitness Walking. Orient Paperbacks, New Delhi (1993). 